\title{
Spinal Cord Injury: An Under Recognized Cardiovascular Disease Risk Factor
}

\author{
Heidi L Lujan and Stephen E DiCarlo* \\ Department of Physiology, Michigan State University, USA
}

Submission: December 22, 2017; Published: January 19, 2018

*Corresponding author: Stephen E DiCarlo, PhD, Department of Physiology, Michigan State University, College of Osteopathic Medicine, 567 Wilson Rd BPS Room 2201, East Lansing, MI 48824, Tel: 517-884-5143, Fax: 517-432-1967; Email: dicarlos@msu.edu

Keywords: Stroke; Coronary artery disease; Paraplegia; Tetraplegia

\section{Opinion}

Spinal cord injury (SCI) is a devastating, life-changing condition causing paralysis and sensory impairment as well as autonomic dysfunction. In addition, evidence documents a state of chronic inflammation in individuals with SCI [1-4]. Importantly, chronic inflammation is a significant cardiovascular disease risk factor. Furthermore, paralysis can lead to a relatively sedentary life style and a consequent reduction in physical work capacity [58]. Other consequences of inactivity are a higher body weight, a higher percentage of body fat $[9,10]$, skeletal muscle dysfunction [11-14] and a lower forced vital capacity [15-17].

Autonomic dysfunction involves an abnormal and unstable regulation of the of the heart and vasculature [18]. Specifically, hypotension occurs immediately after the injury because of loss of tonic supra-spinal excitatory drive to spinal sympathetic neurons [19]. Subsequently, resting arterial pressure returns toward normal values; however, episodic bouts of hypertension often develop as part of the condition termed autonomic dysreflexia (AD) $[20,21]$. If not treated promptly, the hypertension may produce cerebral and subarachnoid hemorrhage, seizures, and renal failure and may lead to death [22]. Furthermore, autonomic dysregulation of the heart alters cardiac electrophysiology and increases the susceptibility to arrhythmias [23].

The overwhelming consequences of SCI-induced paralysis often overshadows the fact that inactivity, chronic inflammation and autonomic dysfunction increase the risk of stroke, coronary heart disease, diabetes and, possibly death [9,24-30]. Specifically, individuals living with SCI have an increased risk of heart disease and stroke [31]. Furthermore, individuals living with SCI have a three-fold greater risk of developing cardiovascular disease (CVD) than their able-bodied counterparts [31]. Importantly, the magnitude of CVD risk is heavily dependent on the level of SCI, whereby individuals with tetraplegia have a $16 \%$ greater risk of all-cause CVD than individuals with paraplegia [32-35]. As noted, the risk for significant cardiovascular disease is mediated, in part, by reduced physical inactivity, dyslipidemia, blood pressure irregularities, chronic inflammation, and abnormal glycemic control [1-3,28,36-49].

Despite this increased risk of cardiovascular disease $[31,50]$, many health care providers are unaware of the complications associated with SCI [51-56] as there is generally little undergraduate or postgraduate training on SCI $[52,54,56,57]$. Even knowledge of life threatening conditions, such as autonomic dysreflexia, are unknown among many physicians outside the rehabilitation or neurologic specialties [58]. Thus, additional information regarding the cardiovascular risks associated with SCI has the potential to improve the quality of life for individuals and families living with SCI. An understanding of the unique medical conditions related to SCI is an important first step because cardiovascular complications are important and potentially serious conditions.

In summary, individuals living with spinal cord injury have an increased risk for heart disease and stroke. Furthermore, cardiovascular disease is the leading cause of death and morbidity. The risk for cardiovascular disease is associated with an unstable autonomic control of the heart and vasculature, a relatively sedentary lifestyle, chronic inflammation and blood lipid profiles consisting of elevated total and low-density lipoprotein cholesterol and depressed high-density lipoprotein. Relative inactivity associated with SCI also results in a reduced muscle mass and increased adiposity. Accordingly, individuals living with SCI often experience insulin resistance, hyperinsulinemia and an atherogenic profile that contributes to early development of cardiovascular disease. Impairments in autonomic function markedly impacts blood pressure control [18] and promote 
the development of cardiac arrhythmias [59-63]. Thus, autonomic dysfunction, relative inactivity and adverse changes in body composition lead to metabolic changes that promote cardiovascular disease in individuals living with SCI. Increasing awareness of these facts has the potential to positively impact individuals and families living with SCI (Figure 1).

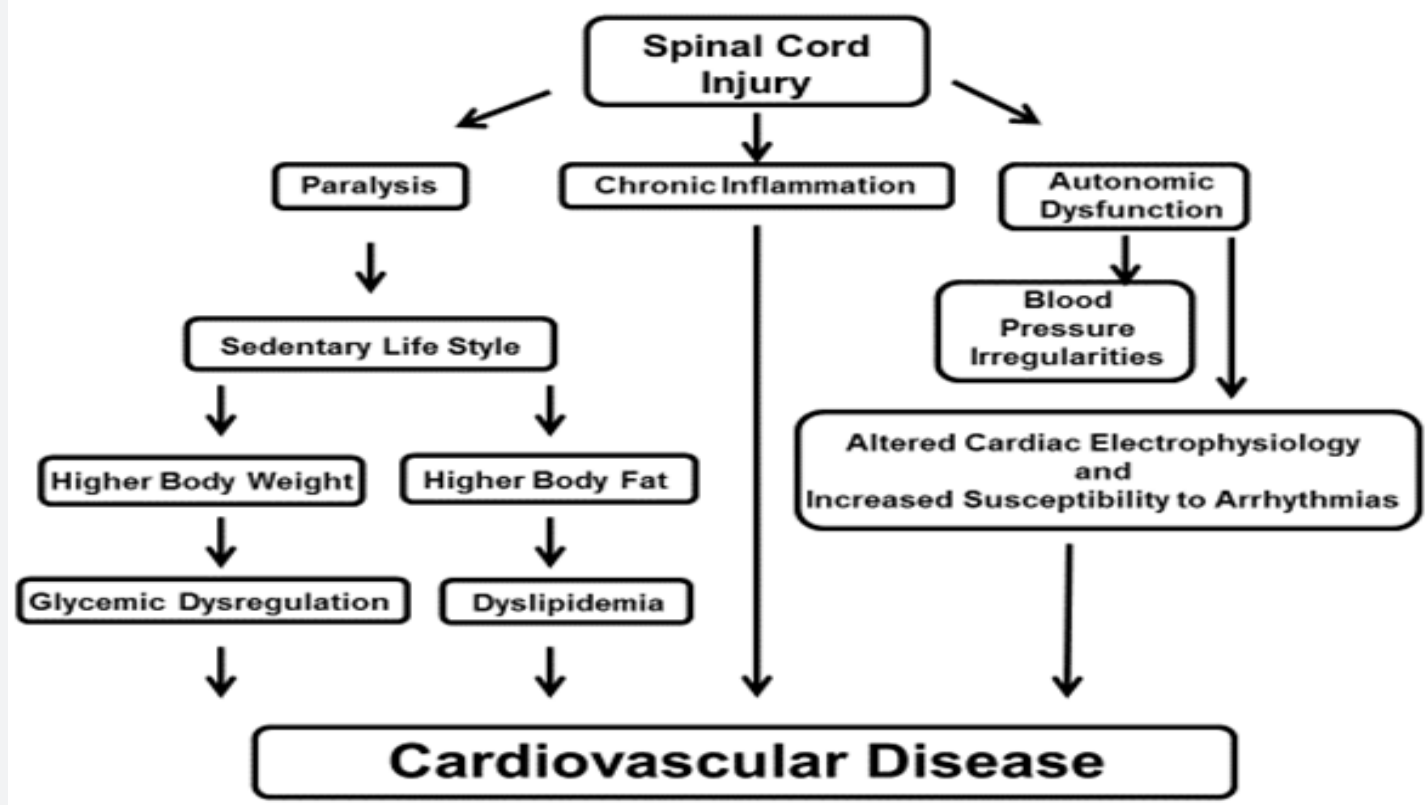

Figure 1: Spinal cord injury induced paralysis, chronic inflammation and autonomic dysfunction accelerate the development of cardiovascular disease in individuals living with spinal cord injury.

\section{Acknowledgement}

This work was supported by National Heart, Lung, and Blood Institute Grant R01HL-122223.

\section{References}

1. Frost F, MJ Roach, I Kushner, Schreiber P (2005) Inflammatory C-reactive protein and cytokine levels in asymptomatic people with chronic spinal cord injury. Arch Phys Med Rehabil 86(2): 312-317.

2. Gibson AE, Buchholz AC, Martin Ginis KA (2008) C-Reactive protein in adults with chronic spinal cord injury: increased chronic inflammation in tetraplegia vs paraplegia. Spinal Cord 46(9): 616-621.

3. Lee MY, Myers J, Hayes A, Madan S, Froelicher VF, et al. (2005) C-reactive protein, metabolic syndrome, and insulin resistance in individuals with spinal cord injury. J Spinal Cord Med 28(1): 20-25.

4. Lutgens E, Daemen MJ, Muinck ED, Debets J, Leenders P, et al. (1999) Chronic myocardial infarction in the mouse: cardiac structural and functional changes. Cardiovasc Res 41(3): 586-593.

5. McKinley W, Garstang S, Wieting J, Talavera F, Foye P, et al. (2016) Cardiovascular Concerns in Spinal Cord Injury.

6. DiCarlo SE (1982) Improved cardiopulmonary status after a two-month program of graded arm exercise in a patient with $\mathrm{C} 6$ quadriplegia: a case report. Phys Ther 62(4): 456-459.

7. DiCarlo SE, Supp MD, Taylor HC (1983) Effect of arm ergometry training on physical work capacity of individuals with spinal cord injuries. Phys Ther 63(7): 1104-1107.

8. DiCarlo SE (1988) Effect of arm ergometry training on wheelchair propulsion endurance of individuals with quadriplegia. Phys Ther 68(1): 40-44

9. Oscai LB (1973) The role of exercise in weight control. Exerc sport Sci Rev 1: 103-123.
10. Edwards LA, Bugaresti JM, Buchholz AC (2008) Visceral adipose tissue and the ratio of visceral to subcutaneous adipose tissue are greater in adults with than in those without spinal cord injury, despite matching waist circumferences. Am J Clin Nutr 87(3): 600-607.

11. Dreyer HC, Glynn EL, Lujan HL, Fry CS, DiCarlo SE, et al. (2008) Chronic paraplegia-induced muscle atrophy down regulates the mTOR/S6K1 signaling pathway. J Appl Physiol 104(1): 27-33.

12. Drummond MJ, Glynn EL, Lujan HL, DiCarlo SE, Rasmussen BB (2008) Gene and protein expression associated with protein synthesis and breakdown in paraplegic skeletal muscle. Muscle Nerve 37(4): 505513.

13. Glynn EL, Lujan HL, Kramer VJ, Drummond MJ, DiCarlo SE, et al. (2008) A chronic increase in physical activity inhibits fed-state mTOR/S6K1 signaling and reduces IRS-1 serine phosphorylation in rat skeletal muscle. Appl Physiol Nutr Metab 33(1): 93-101.

14. Fry CS, Drummond MJ, Lujan HL, DiCarlo SE, Rasmussen BB (2012) Paraplegia increases skeletal muscle autophagy. Muscle Nerve 46(5): 793-798.

15. Zwiren LD, Bar OO (1975) Responses to exercise of paraplegics who differ in conditioning level. Med Sci Sports 7(2): 94-98.

16. West CR, Campbell IG, Shave RE, Romer LM (2012) Resting cardiopulmonary function in Paralympic athletes with cervical spinal cord injury. Med Sci Sports Exerc 44(2): 323-329.

17. Gupta N, White KT, Sandford PR (2006) Body mass index in spinal cord injury-a retrospective study. Spinal Cord 44(2): 92-94.

18. Rodenbaugh DW, Collins HL, DiCarlo SE (2003) Paraplegia differentially increases arterial blood pressure related cardiovascular disease risk factors in normotensive and hypertensive rats. Brain Res 980(8): 242248.

19. Calaresu FR, Yardley CP (1988) Medullary basal sympathetic tone. Ann Rev Physiol 50: 511-524. 
20. Mathias CJ, Frankel HL (1992) The Cardiovascular System in Tetraplegia and Paraplegia. Handbook of Clinical Neurology, Amsterdam, Pp. 435456

21. Naftchi NE (1990) Mechanism of autonomic dysreflexia: Contributions of catecholamine and peptide neurotransmitters. Ann New York Acad Sci 579: 133-148.

22. McGuire TJ, Kumar VN (1986) Autonomic dysreflexia in the spinal cord injured: what the physician should know about this medical emergency. Postgrad Med 80(2): 81-89.

23. Lujan H, DiCarlo S (2016) Alterations in cardiac electrophysiology after sinal cord injury and implications for exercise. In: Taylor J (ed.), The Physiology of Exercise in Spinal Cord Injury. Physiology in Health and Disease. Boston, USA, pp. 77-103.

24. Morris JN, Kagen A, Pattison DC, Gardiner MJ (1966) Incidence and prediction of ischemic heart disease in London busmen. Lancet 2(7463): 553-559.

25. Ressl J, Chrastek J, Jandova R (1977) Haemodynamic effects of physical training in essential hypertension. Lancet 32: 121-133.

26. Naughton JP, Hellerstein HK (1977) Exercise testing and exercise training in coronary heart disease. New York, USA.

27. National Heart Institute (1966) The Framingham heart study: habits and coronary heart disease. Bethesda, USA.

28. Bauman WA, Spungen AM (2008) Coronary heart disease in individuals with spinal cord injury: assessment of risk factors. Spinal Cord 46(7): 466-476.

29. Bauman WA, Adkins RH, Spungen AM, Herbert R, Schechter C, et al. (1999) Is immobilization associated with an abnormal lipoprotein profile? Observations from a diverse cohort. Spinal Cord 37(7): 485493.

30. Paffenbarger RS, Laughlin ME, Gima AS, Black RA (1970) Work activity in longshoreman as related to death from coronary artery disease and stroke. New Engl J Med 282(20): 1109-1114.

31. Cragg JJ, Noonan VK, Krassioukov A, Borisoff J (2013) Cardiovascular disease and spinal cord injury: results from a national population health survey. Neurology 81(8): 723-728.

32. Groah SL, Weitzenkamp D, Sett P, Soni B, Savic G (2001) The relationship between neurological level of injury and symptomatic cardiovascular disease risk in the aging spinal injured. Spinal Cord 39(6): 310-317.

33. Banerjea R, Sambamoorthi U, Weaver F, Maney M, Pogach LM, et al (2008) Risk of stroke, heart attack, and diabetes complications among veterans with spinal cord injury. Arch Phys Med Rehabil 89(8): 14481453.

34. Yekutiel M, Brooks ME, Ohry A, Yarom J, Carel R (1989) The prevalence of hypertension, ischaemic heart disease and diabetes in traumatic spinal cord injured patients and amputees. Paraplegia 27(1): 58-62.

35. Wu JC, Chen YC, Liu L, Chen TJ, Huang WC, et al. (2012) Increased risk of stroke after spinal cord injury: a nationwide 4-year follow-up cohort study. Neurology 78(14): 1051-1057.

36. Liang H, Mojtahedi MC, Chen D, Braunschweig CL (2008) Elevated C-reactive protein associated with decreased high-density lipoprotein cholesterol in men with spinal cord injury. Arch Phys Med Rehabil 89(1): 36-41.

37. Wang TD, Wang YH, Huang TS, Su TC, Pan SL, et al. (2007) Circulating levels of markers of inflammation and endothelial activation are increased in men with chronic spinal cord injury. J Formos Med Assoc 106(11): 919-928.

38. Davies AL, Hayes KC, Dekaban GA (2007) Clinical correlates of elevated serum concentrations of cytokines and autoantibodies in patients with spinal cord injury. Arch Phys Med Rehabil 88(11): 1384-1393.
39. Mahoney ET, Bickel CS, Elder C, Black C, Slade JM, et al. (2005) Changes in skeletal muscle size and glucose tolerance with electrically stimulated resistance training in subjects with chronic spinal cord injury. Arch Phys Med Rehabil 86(7): 1502-1504.

40. Karlsson AK, Attvall S, Jansson PA, Sullivan L, Lönnroth P (1995) Influence of the sympathetic nervous system on insulin sensitivity and adipose tissue metabolism: a study in spinal cord-injured subjects. Metabolism 44(1): 52-58.

41. Bauman WA, Spungen AM (1994) Disorders of carbohydrate and lipid metabolism in veterans with paraplegia or quadriplegia: a model of premature aging. Metabolism 43(6): 749-756.

42. Lieberman JA, Hammond FM, Barringer TA, Norton HJ, Goff DC, et al. (2011) Comparison of coronary artery calcification scores and National Cholesterol Education program guidelines for coronary heart disease risk assessment and treatment paradigms in individuals with chronic traumatic spinal cord injury. J Spinal Cord Med 34(2): 233-240.

43. Heldenberg D, Rubinstein A, Levtov O, Werbin B, Tamir I (1981) Serum lipids and lipoprotein concentrations in young quadriplegic patients. Atherosclerosis 39(2): 163-167.

44. Brenes G, Dearwater S, Shapera R, LaPorte RE, Collins E (1986). High density lipoprotein cholesterol concentrations in physically active and sedentary spinal cord injured patients. Arch Phys Med Rehabil 67(7): 445-450.

45. Bauman WA, Spungen AM, Zhong YG, Rothstein JL, Petry C, et al (1992) Depressed serum high density lipoprotein cholesterol levels in veterans with spinal cord injury. Paraplegia 30(10): 697-703.

46. Krum H, Howes LG, Brown DJ, Ungar G, Moore P, et al. (1992) Risk factors for cardiovascular disease in chronic spinal cord injury patients. Paraplegia 30(6): 381-388.

47. Zlotolow SP, Levy E, Bauman WA (1992) The serum lipoprotein profile in veterans with paraplegia: the relationship to nutritional factors and body mass index. J Am Paraplegia Soc 15(3): 158-162.

48. Schmid A, Halle M, Stützle C, König D, Baumstark MW, et al. (2000) Lipoproteins and free plasma catecholamines in spinal cord injured men with different injury levels. Clin Physiol 20(4): 304-310.

49. Ozgurtas T, Alaca R, Gulec M, Kutluay T (2003) Do spinal cord injuries adversely affect serum lipoprotein profiles? Mil Med 168(7): 545-547.

50. Garshick E, Kelley A, Cohen SA, Garrison A, Tun CG, et al. (2005) A prospective assessment of mortality in chronic spinal cord injury. Spinal Cord 43(7): 408-416.

51. McColl MA, Forster D, Shortt SE, Hunter D, Dorland J, et al. (2008) Physician experiences providing primary care to people with disabilities. Healthc Policy 4(1): e129-147.

52. Donnelly C, McColl MA, Charlifue S, Glass C, O'Brien P, et al. (2007) Utilization, access and satisfaction with primary care among people with spinal cord injuries: a comparison of three countries. Spinal Cord 45(1): 25-36

53. Blackmer J (2003) Rehabilitation medicine: 1. Autonomic dysreflexia CMAJ 169(9): 931-935.

54. Middleton JW, Leong G, Mann L (2008) Management of spinal cord injury in general practice-part 1. Aust Fam Physician 37(4): 229-233.

55. Mann L, Middleton JW, Leong G (2007) Fitting disability into practice-focus on spinal cord injury. Aust Fam Physician 36(12): 1039-1042.

56. Morrison EH, George V, Mosqueda L (2008) Primary care for adults with physical disabilities: perceptions from consumer and provider focus groups. Fam Med 40(9): 645-651.

57. Marks M.B, Teasell R (2006) More than ramps: accessible health care for people with disabilities. CMAJ 175(4): 329-331. 
58. Krassioukov A, Warburton DE, Teasell R, Eng JJ (2009) A systematic review of the management of autonomic dysreflexia after spinal cord injury. Arch Phys Med Rehabil 90(4): 682-695.

59. Rodenbaugh DW, Collins HL, DiCarlo SE (2003) Increased susceptibility to ventricular arrhythmias in hypertensive paraplegic rats. Clin Exp Hypertens 25(6): 349-358.

60. Rodenbaugh DW, Collins HL, Nowacek DG, DiCarlo SE (2003) Increased susceptibility to ventricular arrhythmias is associated with changes in $\mathrm{Ca}^{2+}$ regulatory proteins in paraplegic rats. Am J Physiol Heart Circ Physiol 285(6): H2605-H2613.
61. Collins HL, Rodenbaugh DW, DiCarlo SE (2006) Spinal cord injury alters cardiac electrophysiology and increases the susceptibility to ventricular arrhythmias. Prog Brain Res 152: 275-288.

62. Lujan HL, DiCarlo SE (2007) T5 spinal cord transection increases susceptibility to reperfusion-induced ventricular tachycardia by enhancing sympathetic activity in conscious rats. Am J Physiol Heart Circ Physiol 293(6): H3333-H3339.

63. Lujan HL, Chen Y, Dicarlo SE (2009) Paraplegia Increased Cardiac NGF Content, Sympathetic Tonus and the Susceptibility to IschemiaInduced Ventricular Tachycardia in Conscious Rats. Am J Physiol Heart Circ Physiol 296(5): H1364-1372.

This work is licensed under Creative Commons Attribution 4.0 License

DOI: $10.19080 /$ JOCCT.2018.09.555756

\section{Your next submission with Juniper Publishers will reach you the below assets}

- Quality Editorial service

- Swift Peer Review

- Reprints availability

- E-prints Service

- Manuscript Podcast for convenient understanding

- Global attainment for your research

- Manuscript accessibility in different formats

( Pdf, E-pub, Full Text, Audio)

- Unceasing customer service

Track the below URL for one-step submission https://juniperpublishers.com/online-submission.php 